\title{
IMPLEMENTATTION OF THE COMMON EUROPEAN SECURITY AND DEFENCE POLICY IN THE CONTEXT OF ITS MILITARY ASPECT
}

\author{
Venelin Terziev ${ }^{1}$, Svilen Stefanov ${ }^{2}$, Vanya Banabakova ${ }^{3}$ \\ ${ }^{1}$ Corresponding Member of the Russian Academy of Natural History, Moscow, Russia, Prof. \\ D.Sc. (Ec.), D.Sc. (National Security),D.Sc. (Social Activities), Ph.D., National Military University \\ 2Prof, Ph.D., National Military University, Veliko Tarnovo, Bulgaria, sestefanov@abv.bg \\ Veliko Tarnovo, Bulgaria; University of Rousse, Rousse, Bulgaria, terziev@skmat.com \\ ${ }^{3}$ Prof. Ph.D., National Military University, Veliko Tarnovo, Bulgaria, email: v.banabakova@abv.bg
}

\begin{abstract}
This paper examines the importance and specificities of the common European security and defence policy. The realization of the common European security requires the establishment of a joint European defence. The national security and defence strategies of EU member states are an expression of a concrete implementation of a pan-European policy vision in this area, refracted through the national features of each country. The common stance and purpose of the different countries presuppose cooperation and joint action in the fight against international terrorism, and by virtue of the tasks they perform, intelligence agencies are called upon to play a leading role in this fight.
\end{abstract}

Keywords: General European policy, Security, Defence.

\section{INTRODUCTION}

The situation in the world during the last few decades characterizes with dynamic transformation of international relations. There is a trend noticed, for crashing the model of the national state, which until recently was able to exist independently because the politics, business, security and even the culture are internationalizing, and each one of these spheres becomes much more dependent on outside factors. After the two-pole confrontation era, disintegration of multinational states started, a trend for strengthening the economic and political positions of significant number of states and their integration unions appears. The lack of stable statehood in some states and regions, the occurrence of energy and economic crisis, global terrorism and the weapons and drugs spreading led to crises and armed conflicts arising. An important feature of modern security environment is the integration of individual states and extension of the cooperation among them, with which they objectively keep their common interests in many international security issues, including counteraction to weapons for mass destruction spreading, regional conflicts prevention and regulation, international terrorism and drug dealing fight, sharp global-scale ecological 
problems solving, migration processes control.

The fast changing geopolitical situation and the necessity for managing all the threats and challenges outline clearly the actuality of the topic for establishing security on the European continent, necessity of multi-aspect cooperation, building structures in the field of security and introduction of a clause for common defence that unites the EU member states.

Object of the exposition is study of the EU national security and defence policy. Security is an important characteristic of modern society. Republic of Bulgaria is a state of centuries-long history and rich cultural traditions but also of unique strategic position in Europe, even appearing to be outside border for the European Union. The state's security and particularly, its national security is a system of views for ensuring the security of the individual, of society and of the state from exterior and interior threats in all spheres of social life. National security includes ensuring favourable conditions for the state's economic and social development, for global and regional stability preservation, protection of cultural, spiritual-moral, historical traditions.

Ensuring military safety appears to be a dignificant direction within the natunal security realization.

In many countries, including Bulgaria, the problem with the refugees and terrorism of cross-border that threaten world security intensified sharply. This preconditions the necessity of the whole international community's uniting the efforts, enhancing the effectivity of the used forms and methods to fight that threat, the adoption of quick measures for its neutralization.

Subject of the present study is reviewing the significance and the specific characteristics of the Common European Security and Defence Policy. The common European security realization requires establishment of common European defence. The national security and defence strategies of the EU member states are expression of particular application of common European view for policy in this field in the light of the national characteristics of each one of the states. The common position and goal of the states suggest cooperation and joint activities in the fight against international terrorism, and according to the tasks they fulfil, the intelligence agencies are called to play leading role in that fight.

One of the important strategic directions of the Republic of Bulgaria's military security appears to be the effective interaction and cooperation with the participating states in NATO and the EU. National security requires effective membership in NATO and the EU, and suggests active foreign policy of enhanced responsibilities at observing the principles and norms of international law, contribution to the international peace and security, integration and mutually beneficial collaboration, joint activities, union's operations for stabilizing conflict regions around the world, contribution to the global fight against terrorism.

The contract for accepting Bulgaria into the European Union was signed on April 25th, 2005 and since January 1st, 2017 our country is a full member of the community.

Our membership is part of the process of extension of the European Union, which means spreading of the institutions of supranational governing and the socialization of the new states into the governing structures. This concerns also their foreign policies to a significant extent, which means also connecting the European extending with the European order and security.

Two notions - „security and integration”, can shortly express the meaning of the Common European Security and Defence Policy (CESDP) for Bulgaria. EU strives to establish zone of security, stability and prosperity in Europe. Integrating Bulgaria in the process of establishing a Common European defence is one of the aspects of our country's common policy.

The shaping of Bulgaria's policy for contributing to the Common European Security and Defence Policy (CESDP) is to be based on the understanding that this way the country's positions regarding the processes of integration strengthen and it would allow taking more active participation in the establishing of stability and security zone in Europe.

The expose's goal is to specify the exact role of CESDP in the realization of security and in the managing with all the threats. CESDP is a unique system for cooperation of the EU member states, but through preserving national interests in an environment of mutual dependence, systematic cooperation and development of pragmatic and mutually beneficial relationships.

The set goal is specified through review of the following tasks:

Reviewing national security's military aspect;

Historical ereview of the idea for establishing cooperation in the field of security within the frame of the EU; 
IJASOS- International E-Journal of Advances in Social Sciences, Vol. IV, Issue 12, December 2018

Realization of the EU's CSDP;

Participation of the Republic of Bulgaria and the other European countries in ensuring the European security; Nowadays condition of the European defence policy - actions of regulatory, organizational and other nature.

\section{NATIONAL SECURITY'S MILITARY ASPECT}

Security is functional status of a certain system that that ensures neutralization and its counteraction to exterior and interior factors, which influence or might influence the system destructively (system's organizational status worsening or inability for its functioning and progress). As a principle, security secures physical bodies' life and health, the state, the juridical bodies and their activity as well as the business on the behalf of potential and/or real threats. The high level of security of the individual, the community, the state, enhances their possibilities for progress and well-being. Security is the second step after the physiological needs in the Maslow's Pyramid. In 1954, Maslow defines his pyramid (hierarchy) of human needs, which plays crucial role for the development of human resources and the motivation theory. The pyramid consists of the following five levels and the second is namely - the need of safety, security and ease. Maslow believes that the lower levels' needs are stronger than the ones of the higher ones and that each lower level need should be relatively well satisfied before passing to higher level need satisfaction. New dimensions of security in modern society, however, are built mainly upon the thesis it is a dynamic status of the human and society, which is available or missing at a certain moment (Georgiev, 2011a; Darzhaven vestnik; 2011b; Ministry of Defense, 2018a; Natsionalna programa, 2014a; Stoychev, 2015a; Strategiya, 2011c; 2017a; Tsitseron, 1983a; Uitni, 2009a; Havel, 1993a; Maslow, 1943a; Buzan, B., Wæver, De Wilde, 1998a; 2017b; 2017c; 2017d; 2017e; 2017f; 2017g, 2017h; 2017i).

A feature of the term "security" is its excessively wide scope allowing various interpretations depending on the ideas and interests of the concerned participants. The term's wide scope is result of the fact that the idea for security is in the base of the political thought throughout the whole period of human progress. The ideas of security are changing together with the ideas of political thinking. Particularly bright are the changes in the periods of great social crisis and conflicts.

There are several approaches towards clearing the genesis of the term "security". Historically, the first ever understanding of security is the view of security as individual good. This idea survives the longest and embraces the time of slave-holding and feudal states. The Latin name „securitas” concerning its classical use regards the status of individuals and is connected with their inside status mainly. Cicero calls this status "calmness", „freedom from concerns", "lack of trouble regarding what human life is dependable on”. In later historical periods the term acquires wide meanings, exceeding the notion of security as individual good and starts gradually to fill up with social contents. The Great French Revolution introduces the idea, not only conceptually but also as practical policy, that security is the protection the state renders to each citizen for preserving his freedom, property, honour and dignity.

The new idea of security as collective good that has to be ensured by military and diplomatic tools, dominates in governing the states after the bourgeois revolutions. The individuals and the state are reviewed as synonyms: individuals are the essence of state as the vice versa is true.

The new idea of security extends in three major directions in the $19^{\text {th }}$ and the $20^{\text {th }}$ century: First, the concept of security extends horizontally, i.e. from the point of view of the types of security. Gradually, the concept of security includes military, economic, social, ecological, health, demographic aspects. Second, from national states' security, it is passed to international systems or to the external environment that exceeds the national interests' frames. Thus, the concept of security progresses in ascending direction. Third, although less visible during the first half of the $20^{\text {th }}$ century, the concept of security extends vertically - it goes from security of nation to the security of separate individuals.

The emphasis upon the last aspect of the security concept change became visible after the revolutions in the end of the 80s in Eastern Europe. The former Czech president Vaclav Havel writes: „The security of society, of region and state has meaning only when it is consequence of primal security. This is the security of the separate individual." The notion for the necessity of transiting from territorial security to security of people in their homes, at their work or in the society is established.

Thus the historical review shows the complete cycle of the view for the security - from an individual good through the security of nations - states, security in the international systems and again to the primordial purpose of security, set in the human nature itself as freedom from concerns about everything human existence depends on.

Until the 80 s of the $20^{\text {th }}$ century, thinking about the issue with the national security is dominated by the 
debate between the two main schools in international relations - liberalism and realism. Liberalism followers tend to review peace as guarantee for security. On their turn, within the strongly polarized atmosphere of the Second World War and the following Cold War, realists perceive security as derivative function of states' military power. Thus, the term "security"is conceptually shrinked to measure for the stability of balance of powers or for the power of a state or groups of states in their fight for dominating position.

The adoption of wider approach towards the security analysis is based on the precondition that the term should get out of its traditional field of definition as phenomenon of war and "science about the threat, the use and control of military power". In their theoretic frame, B. Buzan, O. Wæver and J. De Wilde broaden the study agenda through "securitizing" certain problems in the economic and social sector as well as in the sphere of environment by including military-political dimensions, which characterize the traditional study of the term.

Buzan defines the sectors in the analysis of security the following way: military sector regards the two-layer interaction between the armed offensive and defensive abilities of the states and their perceptions about their mutual intentions one against the other. Political security is associated with the states' stability, the systems of governing and the ideologies that give them legitimacy. Economical security regards the access to resources, finances and markets, necessary for maintaining the desired levels of prosperity and state authority. Social security regards the stability of language, culture, religious and national identity and traditions within the desired conditions of development. Ecological security suggests the preservation of local and planetary biosphere as basic maintaining system all the rest human undertakings are dependable on.

Contents of the military aspect of national security of Bulgaria as part of the European community

Modern security strategies have double purpose - interior and exterior. The exterior purpose is to create transparency of the policy of security for neighbouring states, partners, and allies, to dispel doubts about undertaken aggressive policy or territorial pretensions. The interior purpose of strategies is to mobilize and synchronize institutions' efforts in order synergic effect in the security activities to be achieved.

The Bulgarian state has no traditions in creating public documents in the field of security at all. The concept for national security, adopted in 1998 is the first public document created by the Bulgarian state of that type. The concept played its role - in interior aspect, to systematizing of the new principles of the policy of security, to the organization of the activities of security, and in exterior aspect - with laying the foundation of transparent policy of security, which does not create fears among neighbouring states and future allies for hidden intentions for revenge or for returning to non-democratic forms of governing.

Thus, the adoption of Conception for national security in 1998 gave for the first time direction for formulating a definition of national security, which found development in the regulatory through the Classified Information Protection Act and the State Agency for National Security Act.

The Conception had particular meaning for the public announcing of the values, goals, principles and mechanisms of the national security policy before the society and our potential NATO allies. The document turned base for elaboration of the Military Doctrine of the Republic of Bulgaria and of other strategic and regulatory documents.

The 2005 and 2008 elaborated projects of strategies in the field of national security did not reach adoption procedure. Their elaboration process however, gave possibility for evaluating the dynamics of national goals and interests, the changes in the security environment and the ensuing requirements towards the security policy.

In the end of 2010 the National Assembly adopted National Security Strategy. The positive aspects and the disadvantages of the strategic document are analyzed in details in the study. It is noted that usefulness of each newly adopted strategic document has been checked through the effects it produces in public space. The positive changes that would eventually occur in the security sector after adopting the new strategy could hardly be envisaged now. More important is for it to be looked at as obligatory document not a boring formality required for report before the allies from the Alliance.

The National Security Strategy formulates goals and tasks resulting from the adopted model of guaranteeing our state's national security, over which public consensus was achieved in the end of the $20^{\text {th }}$ and the beginning of the $21^{\text {st }}$ century.

It is important to be known that whatever model of security a state chooses and maintains at a certain stage of its development, it cannot be completely new, not connected with the geopolitical context, in which the state has been existed in the course of centuries. There are elements presenting obligatory in this model, regarding geographical positio, size, historical neighbours, resource possibilities, geopolitical preconditioned 
relations, technological, military and resource dependence on another state /states/. Each security model has its historical roots. It is product of positive and at the same time negative historical experience - use of useful elements from previous historical models and rejection of ones that had not withstand the test of history. It is generally acknowledged that there is a great discrepancy between the abilities for guaranteeing the security of big and small states, which has predetermined various historical models for guaranteeing their security. From security point of view, Bulgaria is in the category of "small states", which has predetermined the former historical models for guaranteeing its security. The "small state" security dilemma has negative as well as positive side. The negative one lies within the fact that the state constantly strives for more security, looking for the protection of a great power, and, at the same time, recognizes the possibility for the protection to transform into loss of autonomy. The positive side of this model is that the "small state" can rely, because of its insignificance, on not being object of aggression or conflict by the big states.

Each state's security model reflects historically the level of its orientation towards the world - whether it follows traditionally opened or closed policy; whether her interior or exterior goals achievement, or eventual threats elimination is based on own forces or on collective efforts.

The specifics of Republic of Bulgaria's security model is connected with the fact that the word goes about the security of a small state that exists in one of the most complicated geopolitical regions of modern world.

Before all, this specifics lie in the fact that its national security has always been dependent on exterior rather than interior factors. Its own power /political, economic, military/ has not been sufficient to oppose in eventual conflict of its neighbours.

Security possibilities for most of the so-called "small states" throughout all former times have included three alternatives:

- Binding the state with powerful state as close ally or satellite; insignificant and not necessary addition to the political, economic and military resources of the big state /paternalistic security model/;

- Balancing between the interests of various foreign interests and achieving the own goals through balancing these interests without political and military bonding /policy of neutrality, of non-alignment/;

- Policy of isolation as rarely met model, characterized by low level of binding and interaction with the rest of the units in the international relationships system /in the past Burmah, Albania, now North Korea/.

After Republic of Bulgaria joining NATO and the European Union (EU), its security strategy does not limit within national frame but presents part of our allies' efforts. The risks and threats for the Republic of Bulgaria's security and its citizens coincide to a high extent or are similar to the ones that threat other states from EU and NATO, too.

The dynamics of existing and arising new threats and risks for the citizens and the society of criminal and trans-national nature require new approach in elaborating the security strategy regarding the relevant change and its parameters.

The adapting to the changing security environment imposes new grading of security policy priorities, society's entire institutional potential, application of new forms of interaction between the state, the business and the non-governmental sector such as public-private partnership is. Security policy's social scope extension puts new challenges in front of the institutional coordination along the vertical and the horizontal axes of hierarchy of the connections for governing. Institutions and their structural sections need to act as integrated components of the national security's system.

The policies for counteracting to the risks and threats for the national security and for guaranteeing the protection of citizens and democratic institutions are an organic part of the joint efforts in EU and NATO that lead to the realization of the view for a united space of freedom, security and justice. Realizing the strategic priorities of building a stable and democratic state, where the citizens feel protected exercising their basic rights and obligations, our state is simultaneously overcoming the existing obstacles in front of its further integration within EU and NATO as well as for more effective inclusion in their governance bodies.

The national security strategy embodies the peace-loving nature and good-willed neighbourhood traditions and mutual beneficial cooperation that characterize our state's policy. It is part of the efforts of the EU and NATO towards extending the zone of stability, cooperation and prosperity through terrorism and extremism threats neutralization, regional conflicts overcoming and active participation in global problems' solving. Our state's contribution to stabilizing interstate relations and the application of the principle of non-interference in interior issues of the Balkan peninsular and Black sea region's states is of special significance.

Republic of Bulgaria national security strategy includes the following goal in the part regarding the defence 
policy - protection and recognition of national interests through development, improvement and use of adequate defence capabilities and establishment of unified set of operationally compatible armed forces that are capable of performing the full range of tasks coming from the trends in the geostrategic security environment development.

The formation and conduction of the defence policy is based on:

- The shared responsibility for security, adequate participation and use of the mechanisms of NATO collective defence and EU common security and defence policy;

- The characteristics of security environment, the risks and threats and the resulting scenarios for the armed forces use;

- The status of defence capabilities and the plans for their development;

- The available resources;

- The possibilities for participation in multi-national projects at Bulgarian industry and research centres' active inclusion.

Defence policy strategic goal's performance is based on the states NATO ans EU membership. The effectiveness of our membership in these organizations is of crucial significance for the maximum mastering of the possibilities they render.

The state's contribution to the international community's efforts in the support of peace and stability includes participation in allies' and coalition operations with armed forces formations, security and social order services and with civil capabilities.

Republic of Bulgaria's military forces ensure state's military security, participate in the NATO collective defence and in the EU common security and defence policy's conduction. They are guarantee for the state's sovereignty, independence and territorial integrity.

The armed forces and the institutions ensuring defence capabilities, concentrate their efforts on:

- State's defence;

- Development, maintenance and giving the necessary military and other type of capabilities for NATO collective defence and EU common security and defence policy;

- Participation in missions and operations for strengthening international order and security;

- Building a new system of organization, preparation and usage of voluntary reserve of armed forces for their final completion;

- Maintenance and rendering capabilities as well as forming territorial reserve for peace times in subjection of district governors and municipal mayors for support of the population and protection of national critical infrastructure in preventing and liquidating calamities' and averages' consequences;

- Establishing system for voluntary military preparation of Bulgarian citizens for Fatherland's protection.

The National defence strategy defines the goals, functions, tasks, building, development and use of armed forces and defence capabilities. Defence capabilities' development is analyzed and assessed through conduction of regular reviews of defence or of forces' structures, is realized by the implementation of armed forces development plans and is annually put in defence and armed forces status report.

Defence policy's priority is development of modern defence institution, based on effective defence management integrated system under civil and parliament control. This requires the application of the following:

- Modern defence management, based on effective use of financial resource that ensures the connection between the long-term planning and the achievement of preset results, in compliance with the principles of accounting and transparency;

- Planning, based on capabilities and possible scenarios for their use;

- Technological rearming of the defence system and of the armed forces, while applying the experience from participation in missions and operations, from the achievements and results of the studies in the field of security;

- Preparation and training of the people in defence in compliance with the modern allies' standards; 
- Increasing our participation in structures, programmes and projects jointly with our allies and partners within the agencies of NATO, the European Defence Agency and realization of the EU Security and Innovations Programme; establishing maximum possibilities for the national defence technological and industrial base and research/innovation capabilities inclusion;

- Up-dating of conceptions and doctrines for the development and use of military and civil components of the defence system.

The future of state's interior security is inevitably connected with the dependencies between the interior and the exterior as well as with the interior and military security, and the balance between them is guarantee for the stability of state (Terziev, Petkov, Krastev, 2018b, pp.473-476; Terziev, Petkov, Krastev, 2018c, pp. 477481; Terziev, Petkov, Krastev, 2018d, pp.487-491; Terziev, Petkov, Krastev, 2018e, pp.492-496; Terziev, Petkov, Krastev, 2018f, pp.501-504; Terziev, Petkov, Krastev, 2018g, pp.497- 500; Terziev, Petkov, Krastev, 2018h, pp.505-510; Terziev, Petkov, Krastev, 2018i, pp.482-486; Terziev, Petkov, Krastev, 2018j, pp.511516; Terziev, Petkov, Krastev, 2018k, pp.517-521; Stefanov, Terziev, Banabakova, 2017c, pp.4-10; Stefanov, Terziev, Banabakova, 2017d, pp.31-36; Stefanov, Terziev, Banabakova, 2017e, pp.11-16; Stefanov, Terziev, Banabakova, 2017f, pp.40-49; Terziev, Madanski, Georgiev, 2017g, pp. 748-753; Terziev, Madanski, Georgiev, 2017h, pp. 743-747; Terziev, Madanski, Georgiev, 2017i; pp. 923-927; Terziev, Madanski, Georgiev, 2017j, pp. 1051-1055; Hristov, 2018I, pp. 183-186; Terziev, Madanski, Kanev, 2017k, pp.1380-1393; Terziev, Nichev, 2016a, pp.101-106; Terziev, 2016b, s.84-90; Terziev, 2017l, pp. 1046-1061; Terziev, 2017m, pp. 940-947; Terziev. Stoyanov, Georgiev, 2017n, pp.7-11; Terziev, Nichev, 2017o, pp.502507; Terziev, Stefanov, Banabakova, lliev, 2017p, pp.953-963; Terziev, Stefanov, Banabakova, Iliev, 2017q, pp.741-757).

\section{CONCLUSION}

Security in modern society is a dynamic status of human and the society. Republic of Bulgaria national security is a system of views for ensuring the security of personality, of society and of state from exterior and interior threats in all social life spheres. The most important directions of state policy are formulated in it.

In interior aspect, it characterizes with the functioning of a democratic political system with stable consensus on the basic foreign policy goals and priorities, with guaranteeing legal order and the recognition of human rights and freedoms, with strengthening market economy and ensuring sustainable development as well as with the protection of individual security of citizens.

In international aspect, environment is distinguished for the multi-aspect influence for the processes of globalization and integration, internationalization of the risks and challenges, asymmetric threats, instability in certain regions in the world and the resulting transformation in the main international organizations (UN, NATO, EU).

Republic of Bulgaria follows strategy based on non-traditional, preventive and outstripping approaches and solutions, on coordinated and mutually supplemental efforts for engaging of political, economic, technological, information, military and civil resources of the state for optimal use of the possibilities and for effective overcoming of challenges of that environment. This strategy accounts the inseparable essence of security and the collective environment it is guaranteed in.

State's defence is directed towards building and using capabilities for preventing and opposing crises of military and non-military nature that threaten national security and in support of state authorities and society. The state realizes its defence through conduction of active and purposeful defence policy, which formulates, defines and ensures the achievement of the main goal, the missions and tasks of military forces.

The policy is realized through effective and productive national security strategy, effective membership in the UN, NATO and the European Union. National security suggests active foreign policy of enhanced responsibilities, while observing the principles and norms of international law, contribution to international peace and security as well as participation in collective actions within NATO throughout the whole scope, allies' and coalition's operations for stabilizing conflict regions around the world and contribution to the global war against terrorism.

Republic of Bulgaria's defence policy after its EU membership is directed towards establishment and maintenance of secure environment, favourable for realizing the national interests. It is also an element of the integral state's security policy. Defence policy is conducted in the circumstances of openness and continuity of the main priorities and goals. It is realized in the context of NATO collective defence system and of Bulgaria's European Union membership.

State's defence is pre-orienting to an approach, based on establishment of necessary capabilities in 
response to risks and threats. Republic of Bulgaria armed forces, as bearer of significant part of these capabilities, are in processof dynamic transformation. The main goal of defence - guaranteeing state's sovereignity, security and independence, and protection of its territorial integrity, is realized in the context of collective defence allies' system (NATO) with complete engagement of national capabilities and resources.

Main goal of transformation and basic task of the Ministry of defence is the building of modern and effective system for defence and armed forces with capabilities and staff that are adequate to the national interests and to the requirements of the dynamic security system. The main directions of this development are defined as result of the conducted Strategic review of defence in the period 2003-2004 and defined in the adopted long-term vision for the development of army and forces 2015 by the 39th National Assembly.

The development of army and forces is directed to guaranteeing the maintenance of effective, efficient, multifunctional, module and mobile army units with capabilities for joint actions, for deploying on the territory of state or abroad, relatively independent and comprehensively ensured.

The efforts for ensuring national security are directed towards achieving four main priorities:

Armed forces transformation for effective generating of the necessary operative capabilities;

Procedures and practices transformation for forming and conduction of the security and defence policy;

Effective NATO membership;

Integrating in the system of the European security and defence policy.

West European security model has endured the deepest changes in the course of years. This model establishes mutual interweaving of political, economic, military aspects of security through extension of the main organizations in it, through the structural changes inside each one of them and the adequate interaction between them, which ensures undebatable advantages in the new European architecture of security formation. This is a new type of security in its essence - responsible for solving not only the classical problems of security such as preserving the territorial integrity and sovereignty of West European states, but also the successful solving of interior security problems - social and economic stability and prosperity, cultural and ethnic integrity, security and human rights, etc.

\section{REFERENCE LIST}

Georgiev, Hristo. (2011a). Rezyume na monografichen trud „Politika na sigurnost na Republika Balgariya v nachaloto na XX-vi vek: teoretichni i prilozhni aspekti“; izd. „Stopanstvo“ UNSS, Sofiya, 2011 (Георгиев, Христо. Резюме на монографичен труд „Политика на сигурност на Република България в началото на XX'-ви век: теоретични и приложни аспекти“; изд. „Стопанство“ УНСС, София, 2011).

Darzhaven vestnik. (2011b). Ministerski savet. Postanovlenie nomer 9 ot 20.01.2011g. za priemane na Naredba za usloviyata i reda za uchastie na grazhdanski spetsialisti ot Republika Balgariya $v$ operatsii i misii na mezhdunarodni organizatsii za upravlenie na krizi izvan teritoriyata na Republika Balgariya (Държавен вестник. Министерски съвет. Постановление номер 9 от 20.01.2011г. за приемане на Наредба за условията и реда за участие на граждански специалисти от Република България в операции и мисии на международни организации за управление на кризи извън територията на Република България).

Ministry of Defense. Collaboration. (2018a). Министерство на отбраната. Сътрудничество. Http://www.mod.bg/bg/cooperation.html.

Natsionalna programa „Balgariya v NATO i v Evropeyskata otbrana 2020“ - oktomvri 2014g. (2014a). Ministerski savet (Национална програма „България в НАТО и в Европейската отбрана 2020“ октомври 2014г. Министерски съвет); http://www.strategy.bg/strategicdocuments/View.aspx?Lang=bg-BG\&ld=932.

Stoychev, Stoyan. (2015a). Izsledvane sposobnostite na NATO i Evropeyskiya sayuz v otgovor i upravlenie na krizi; Sofiya, Voenna akademiya „G.S.Rakovski“; 2015 (Стойчев, Стоян. Изследване способностите на НАТО и Европейския съюз в отговор и управление на кризи; София, Военна академия „Г.С.Раковски“; 2015).

Strategiya za natsionalna sigurnost na Republika Balgariya - fevruari 2011g., (2011c). Ministerstvo na 
otbranata na Republika Balgariya - Tsentralno voenno okrazhie, (Стратегия за национална сигурност на Република България - февруари 2011г. Министерство на отбраната на Република България - Централно военно окръжие) http://www.comd.bg/bg/content/strategiya-za-nacionalnasigurnost-na-republika-blgariya.

http://eurlex.europa.eu/LexUriServ/LexUriServ.do?uri=OJ:L:2005:157:SOM:BG:HTML. (2017a).

Tsitseron. Mark Tuliy. (1983a). Izbrani rechi. S., Nauka i izkustvo, 1983 (Veliki oratori), Марк Тулий Цицерон. Избрани речи. С., Наука и изкуство, 1983 (Велики оратори).

Uitni, N. (2009a). Da sazhivim evropeyskata politika za sigurnost i otbrana, Evropeyski savet za vanshna politika, 2009 (Уитни, Н., Да съживим европейската политика за сигурност и отбрана, Европейски съвет за външна политика, 2009).

Havel, Vatslav. (1993a). Letni razmishleniya, izdatelstvo Prosveta, 1993 (Хавел, Вацлав; Летни размишления, издателство „Просвета”, 1993).

Maslow, A.H. (1943a). A Theory of Human Motivation, Psychological Review; 1943.

Buzan, B., Wæver, O., De Wilde, J. (1998a). Security: A New Framework for Analysis. Boulder, Colo.: Lynne Rienner Pub, 1998.

http://europa.eu/about-eu/eu-history/1945-1959/1949/index_bg.htm. (2017b).

http://europa.eu/about-eu/basic-information/symbols/europe-day/schuman-declaration/index_bg.htm. (2017c).

http://ec.europa.eu/bulgaria/abc/eu_glance/eu_timeline/index_bg.htm.(2017d).

http://www.europarl.europa.eu/sides/getDoc.do?pubRef=//EP//TEXT+IMPRESS+20070206STO02783+0+D $\mathrm{OC}+\mathrm{XML}+\mathrm{V}$ O//BG. (2017e).

http://ec.europa.eu/bulgaria/abc/eu_glance/treaties_documents/treaties_bg.htm. (2017f).

http://geopolitica.eu/drugi-statii/934-evropeyskata-politika-za-sigurnost-istoriya-i-perspektivi. (2017g)

http://eur-lex.europa.eu/legal-content/BG/TXT/?uri=uriserv:ai0026. (2017h).

http://www.mod.bg/bg/doc/cooperation/EC/EC_erasmus.pdf. (2017i).

Terziev, V., Petkov, M., Krastev, D. (2018b). Operative mode for police cooperation between the member states of the European Union. // Proceedings of SOCIOINT 2018- $5^{\text {th }}$ International Conference on Education, Social Sciences and Humanities, 2-4 July 2018- Dubai, U.A.E, International Organization Center of Academic Research, www.ocerints.org, pp.473-476, ISBN: 978-605-82433-3-0.

Terziev, V., Petkov, M., Krastev, D. (2018c). European arrest warrant: appearance and preferences for fulfillment. // Proceedings of SOCIOINT 2018- $5^{\text {th }}$ International Conference on Education, Social Sciences and Humanities, 2-4 July 2018- Dubai, U.A.E, International Organization Center of Academic Research, www.ocerints.org, pp. 477-481, ISBN: 978-605-82433-3-0.

Terziev, V., Petkov, M., Krastev, D. (2018d). Eurojust casework on mafia-type criminal organisations. // Proceedings of SOCIOINT 2018- 5th International Conference on Education, Social Sciences and Humanities, 2-4 July 2018- Dubai, U.A.E, International Organization Center of Academic Research, www.ocerints.org, pp.487-491, ISBN: 978-605-82433-3-0.

Terziev, V., Petkov, M., Krastev, D. (2018e). Concept of joint investigation teams. // Proceedings of SOCIOINT 2018- $5^{\text {th }}$ International Conference on Education, Social Sciences and Humanities, 2-4 July 2018- Dubai, U.A.E, International Organization Center of Academic Research, www.ocerints.org, pp.492-496, ISBN: 978-605-82433-3-0.

Terziev, V., Petkov, M., Krastev, D. (2018f). European arrest warrant and human rights of the accused. // Proceedings of SOCIOINT 2018- $5^{\text {th }}$ International Conference on Education, Social Sciences and Humanities, 2-4 July 2018- Dubai, U.A.E, International Organization Center of Academic Research, www.ocerints.org, pp.501-504, ISBN: 978-605-82433-3-0.

Terziev, V., Petkov, M., Krastev, D. (2018g). Pumps for the action on the European Union in the scope of the European agenda on security. // Proceedings of SOCIOINT 2018- $5^{\text {th }}$ International Conference on Education, Social Sciences and Humanities, 2-4 July 2018- Dubai, U.A.E, International Organization Center of Academic Research, www.ocerints.org, pp.497- 500, ISBN: 978-605-82433-3-0. 
IJASOS- International E-Journal of Advances in Social Sciences, Vol. IV, Issue 12, December 2018

Terziev, V., Petkov, M., Krastev, D. (2018h). The process of forming a criminal policy of the European Union. // Proceedings of SOCIOINT 2018- 5th International Conference on Education, Social Sciences and Humanities, 2-4 July 2018- Dubai, U.A.E, International Organization Center of Academic Research, www.ocerints.org, pp.505-510, ISBN: 978-605-82433-3-0.

Terziev, V., Petkov, M., Krastev, D. (2018i). Organization on the European Union in the sphere of penal preparation. // Proceedings of SOCIOINT 2018- $5^{\text {th }}$ International Conference on Education, Social Sciences and Humanities, 2-4 July 2018- Dubai, U.A.E, International Organization Center of Academic Research, www.ocerints.org, pp.482-486, ISBN: 978-605-82433-3-0.

Terziev, V., Petkov, M., Krastev, D. (2018j). Sources of European Union law. // Proceedings of SOCIOINT 2018- $5^{\text {th }}$ International Conference on Education, Social Sciences and Humanities, 2-4 July 2018Dubai, U.A.E, International Organization Center of Academic Research, www.ocerints.org, pp.511516, ISBN: 978-605-82433-3-0.

Terziev, V., Petkov, M., Krastev, D. (2018k). The „Source of law“ category. // Proceedings of SOCIOINT 2018- 5th International Conference on Education, Social Sciences and Humanities, 2-4 July 2018Dubai, U.A.E, International Organization Center of Academic Research, www.ocerints.org, pp.517521, ISBN: 978-605-82433-3-0.

Stefanov, S., Terziev, V., Banabakova, V. (2017c). Razbiraneto za sigurnost v postmodernoto obshtestvo. // International scientific conference „CONFSEC 2017“, 11-14 December 2017, Theoretical foundations of security, national and international security, 1, 2017, N 1(1), ISSN (PRINT) 2603-2945, ISSN (ONLINE) 2603-2953, pp.4-10 (Стефанов, С., Терзиев, В., Банабакова, В. Разбирането за сигурност в постмодерното общество. // International scientific conference „CONFSEC 2017“, 11-14 December 2017, Theoretical foundations of security, national and international security, 1, 2017, N 1(1), ISSN (PRINT) 2603-2945, ISSN (ONLINE) 2603-2953, pp.4-10).

Terziev, V., Stefanov, S., Banabakova, V. (2017d). Realiziraneto na obshtata evropeyska politika za sigurnost i otbrana v konteksta na neyniya voenen aspekt. // International scientific conference „CONFSEC 2017“, 11-14 December 2017, Theoretical foundations of security, national and international security, 1, 2017, N 1(1), ISSN (PRINT) 2603-2945, ISSN (ONLINE) 2603-2953, pp.3136 (Терзиев, В., Стефанов, С., Банабакова, В. Реализирането на общата европейска политика за сигурност и отбрана в контекста на нейния военен аспект. // International scientific conference "CONFSEC 2017“, 11-14 December 2017, Theoretical foundations of security, national and international security, 1, 2017, N 1(1), ISSN (PRINT) 2603-2945, ISSN (ONLINE) 2603-2953, pp.3136).

Terziev, V., Stefanov, S., Banabakova, V. (2017e). Nivata na sigurnost i postmodernoto obshtestvo. // International scientific conference „CONFSEC 2017“, 11-14 December 2017, Theoretical foundations of security, national and international security, 1, 2017, N 1(1), ISSN (PRINT) 2603-2945, ISSN (ONLINE) 2603-2953, pp.11-16 (Терзиев, В., Стефанов, С., Банабакова, В. Нивата на сигурност и постмодерното общество. // International scientific conference „CONFSEC 2017“, 11-14 December 2017, Theoretical foundations of security, national and international security, 1, 2017, N 1(1), ISSN (PRINT) 2603-2945, ISSN (ONLINE) 2603-2953, pp.11-16).

Terziev, V., Stefanov, S., Banabakova, V. (2017f). Obshtata evropeyska politika za sigurnost i otbrana. // International scientific conference „CONFSEC 2017“, 11-14 December 2017, Theoretical foundations of security, national and international security, 1, 2017, N 1(1), ISSN (PRINT) 2603-2945, ISSN (ONLINE) 2603-2953, pp.40-49 (Терзиев, В., Стефанов, С., Банабакова, В. Общата европейска политика за сигурност и отбрана. // International scientific conference „CONFSEC 2017“, 11-14 December 2017, Theoretical foundations of security, national and international security, 1, 2017, N 1(1), ISSN (PRINT) 2603-2945, ISSN (ONLINE) 2603-2953, pp.40-49).

Terziev, V., Madanski, V., Georgiev, M. (2017g). Offset as an economic operation and a trade practice. // Proceedings of ADVED 2017- 3rd International Conference on Advances in Education and Social Sciences 9-11 October 2017- Istanbul, Turkey. International Organization Center of Academic Research, www.ocerint.org, 2017, pp. 748-753, ISBN: 978-605-82433-0-9.

Terziev, V., Madanski, V., Georgiev, M. (2017h). Offset implementation impact on technology transfer in Bulgaria. // Proceedings of ADVED 2017- 3rd International Conference on Advances in Education and Social Sciences 9-11 October 2017- Istanbul, Turkey .International Organization Center of Academic Research, www.ocerint.org, 2017, pp. 743-747, ISBN: 978-605-82433-0-9.

Terziev, V., Madanski, V., Georgiev, M. (2017i). Offset implementation impact on technology transfer in 
Bulgaria. // IJAEDU- International E-Journal of Advances in Education, International Organization Center of Academic Research, www.ocerint.org, 3, 2017, N 9, pp. 923-927, e-ISSN: 2411-18.

Terziev, V., Madanski, V., Georgiev, M. (2017j). Offset as an economic operation and a trade practice. // IJAEDU- International E-Journal of Advances in Education, International Organization Center of Academic Research, www.ocerint.org, 3, 2017, N 9, pp. 1051-1055, e-ISSN: 2411-18.

Hristov, Neno. (2018I). NATO Resilience, Deter and Professional Military Education. Proceedings of INTCESS 2018- 5th International Conference on Education and Social Sciences 5-7 February 2018Istanbul, Turkey, pp. 183-186.

Terziev, V., Madanski, V. Kanev, D. (2017k). Directions for improvement of the military-educational system and its contribution for strengthening national security and the defence of the country. // Sport, Education and Society, Taylor \& Francis, 22, 2017, N 8(2), Source Normalized Impact per Paper (SNIP): 1.459 SCImago Journal Rank (SJR): 1.005 Impact factor: 1.269 Ranking: 60/230 (Education \& Educational Research), 20/44 (Hospitality, Leisure, Sport and Tourism), 51/82 (Sport Sciences), Print ISSN: 1357-3322 Online ISSN: 1470-1243, pp.1380-1393.

Terziev, V., Nichev, N. (2016a). Икономически характеристики на офрсетните сделки с отбранителни продукти (Economic characteristics of offset transactions with defense products). // Scientific journal "Economics and Finance“, Problems of development modern science: Theory and practice Collection of scienfic articles, 2016, ISBN 978-617-7214-33-4, pp.101-106.

Terziev, Venelin. (2016b). Human resource management systems in security and defense: social policies for social activities. // XXXII Mezhdunarodnaya nauchno-prakticheskaya konferentsiya, Evraziyskiy soyuz uchenayh (ESU), Ezhemesyachnayy nauchnayy zhurnal № 12 (33)/ 2016 Chasty 1, Moskva 30.12.2016g., 2016, ISSN 2411-6467, s.84-90 (Terziev, Venelin. Human resource management systems in security and defense: social policies for social activities. // XXXII Международная научнопрактическая конференция, Евразийский союз ученых (ЕСУ), Ежемесячный научный журнал № 12 (33)/ 2016 Часть 1, Москва 30.12.2016г., 2016, ISSN 2411-6467, с.84-90).

Terziev, Venelin. (2017l). Human resource management system in security and defense: social policies for socialactivities. Oxford Economic papers, 69, 2017, N 4(2), pp. 1046-1061, ISSN 0030-7653.

Terziev, Venelin. (2017m). Streamlining management solutions for economic, effective and efficient spending of resources for security and defense. // Oxford Journal of Legal studies, 37, 2017, 4 (2), pp. 940-947, ISSN 0143-6503.

Terziev, V. Stoyanov, E., Georgiev, M. (2017n). The balanced scorecard model as atool for improvement of the national defense system management (Модельт балансирана карта за оценка като инструмент за усъвършенстване на управлението в работата на националната система за отбрана и сигурност). // Research: tendencies and prospects: Collection of scientific articles. - Editorial Arane, S.A. de C.V., Mexico City, Mexico, 2017, ISBN 978-0-9942661-5-6, pp.7-11.

Terziev, V., Nichev, N. (20170). Main features of the offsets in defense trade, // IJASOS- International EJournal of Advances in Social Sciences, 3, 2017, N 8, e-ISSN: 2411-183X, pp.502-507.

Terziev, V., Stefanov, S., Banabakova, V., Iliev, I. (2017p). Implementation of the common European security and defense policy in the context of its military aspect. // Fifteenth International Scientific Conference: Knowledge in practice, Bansko, Bulgaria, International Journal of Knowledge and Learning, Institute of Knowledge Management- Skopje, 20, 2017, N2, pp.953-963, ISSN 1857-923X for e - version, ISSN 2545-4439 for printed version.

Terziev, V., Stefanov, S., Banabakova, V., Iliev, I. (2017q). Common European security and defense policy. // Fifteenth International Scientific Conference: Knowledge in practice, Bansko, Bulgaria. International Journal of Knowledge and Learning, Institute of Knowledge Management- Skopje, 20, 2017, N2, pp.741-757, ISSN 1857-923X for e - version, ISSN 2545-4439 for printed version. 